\title{
CDH3 wt Allele
}

National Cancer Institute

\section{Source}

National Cancer Institute. CDH3 wt Allele. NCI Thesaurus. Code C51152.

Human CDH3 wild-type allele is located in the vicinity of $16 q 22.1$ and is approximately 54 $\mathrm{kb}$ in length. This allele, which encodes cadherin-3 protein, is involved in calciumdependent cell-cell adhesion. Mutations in this gene have been associated with congential hypotrichosis and juvenile macular dystrophy. 